\title{
HUBUNGAN KOMPETENSI GURU, PELAYANAN TENAGA ADMINISTRASI SEKOLAH DAN MOTIVASI BELAJAR SISWA
}

\author{
Ismakrufah \\ Maisyaroh \\ Mustiningsih

\begin{abstract}
Jurusan Administrasi Pendidikan Fakultas Ilmu Pendidikan Universitas Negeri Malang
Jl. Semarang No. 5 Malang 65145 Jawa Timur Indonesia

ismakrufah25@gmail.com
\end{abstract}

\begin{abstract}
The purpose of this study is to determine the relationship of teacher's competence, school administratives services (TAS) and students learning motivation. This research uses a descriptive correlational research design. The population of this study is students who were taken by using systematic proportional random sampling technique. Data analysis used is descriptive analysis technique and double correlation. The result of the research shows that there is a significant correlation between teacher'ers competence and student's learning motivation, there is significant correlation between TAS services and student's learning motivation, there is a significant correlation between teacher's competence, TAS service and student's learning motivation.
\end{abstract}

Keyword : competency service, motivation to learn

\begin{abstract}
Abstrak: Tujuan dari penelitian ini yaitu untuk mengetahui hubungan kompetensi guru, pelayanan Tenaga Administrasi Sekolah (TAS) dan motivasi belajar siswa. Penelitian ini menggunakan desain penelitian yang bersifat deskriptif korelasional. Populasi penelitian ini ialah siswa yang diambil dengan menggunakan teknik sistematis proportional random sampling. Analisis data yang digunakan ialah teknik analisis deskriptif dan korelasi ganda. Hasil dari penelitian menunjukkan bahwa terdapat hubungan yang signifikan antara kompetensi guru dan motivasi belajar siswa, terdapat hubungan yang signifikan antara pelayanan TAS dan motivasi belajar siswa, terdapat hubungan yang signifikan antara kompetensi guru, pelayanan TAS dan motivasi belajar siswa.
\end{abstract}

Kata Kunci: kompetensi, pelayanan, motivasi belajar

Motivasi merupakan dorongan pada diri seseorang untuk berubah menjadi pribadi yang lebih baik lagi dari semula. Motivasi sangat diperlukan dalam melakukan segala kegiatan salah satunya dalam belajar. Motivasi menurut Erlanggono, Kurniawan, dan Sriyono (2012) adalah suatu hal yang mempunyai kekuatan dalam mendorong dan memberikan arah untuk mencapai tujuan tertentu. Dengan adanya motivasi belajar yang tinggi pada diri siswa maka nantinya dapat mengembangkan pengetahuan dan keterampilan dalam diri siswa tersebut. Motivasi dapat berasal dari dalam dan luar. Motivasi yang berasal dari dalam biasanya disebut motivasi intrinsik.
Sedangkan, motivasi yang berasal dari luar disebut motivasi ekstrinsik. Motivasi intrinsik lebih kuat daripada motivasi ekstrinsik. Hal itu terjadi karena pada motivasi intrinsik, motivasi tersebut muncul dikarenakan adanya niat dan keinginan sendiri pada diri individu. Sehingga, bertahannya motivasi intrinsik lebih lama. Sejalan dengan hal itu, menurut Mustiningsih (2009) terdapat dua macam motivasi, yaitu: (1) motivasi intrinsik merupakan motif yang ada dalam diri individu sehingga tidak memerlukan rangsangan dari luar, (2) motivasi ekstrinsik merupakan motif yang tumbuh karena adanya rangsangan dari luar. Fungsi dari motivasi belajar 
menurut Mustiningsih (2009) yaitu: (1) motivasi sebagai pendorong perbuatan, adanya sesuatu yang ingin dicari dan rasa ingin tahu membuat peserta didik terdorong untuk belajar, (2) motivasi sebagai penggerak perbuatan, gerakan psikofisik merupakan kekuatan yang tidak terbendung yang berasal dari dorongan psikologis, (3) motivasi sebagai pengarah perbuatan, peserta didik dapat memilah dan memilih perbuatan yang harus dilakukan dan harus diabaikan melalui motivasi. Dalam suatu sekolah, guru (pendidik) mempunyai peran penting dalam memberikan motivasi baik secara intrinsik maupun ekstrinsik kepada siswa. Karena, dengan adanya motivasi tersebut dapat membuat siswa termotivasi salah satunya termotivasi dalam kegiatan pembelajaran.

Tidak hanya guru saja yang harus memberikan motivasi kepada siswa, melainkan tenaga kependidikan atau biasa disebut dengan Tenaga Administrasi Sekolah (TAS) juga harus memberikan motivasi kepada siswa. Karena, pengelola pendidikan tidaklah guru saja melainkan juga memerlukan tenaga kependidikan. Sehingga, guru dan TAS memiliki peran penting dalam upaya meningkatkan mutu pendidikan di sekolah agar lebih baik lagi. Salah satu upaya untuk memberikan motivasi kepada siswa yang harus dilakukan oleh guru ialah dengan memiliki kompetensi yang baik. Menurut Sopiatin (2010) kompetensi merupakan kemampuan yang dijadikan sebagai standar kinerja individu yang memberikan kontribusi bagi lembaga. Guru yang kompeten menurut Mulyasa (2008) yaitu: (1) mampu bertanggung jawab, (2) ketepatan dalam melaksanakan peran dan fungsinya, (3) mewujudkan tujuan pendidikan melalui pekerjaannya, (4) dalam melakukan pembelajaran di kelas mampu melaksanakan peran dan fungsinya. Sedangkan, yang harus dilakukan oleh tenaga kependidikan ialah dengan cara memberikan pelayanan yang baik kepada siswa. Pelayanan menurut Prihastono (2012) adalah kepuasan yang diperoleh pelanggan melalui perilaku yang dilakukan individu. Tujuan dari pelayanan menurut Zulkarnain \& Sumarsono (2011) ialah: (1) membangun kesetiaan pelanggan, (2) memberikan rasa puas dan kepercayaan pada pelanggan.

Guru dan TAS dapat menilai sendiri kemampuan atau kinerja yang dilakukan itu sudah baik atau belum. Akan tetapi, jika penilaian itu dilakukan melalui siswa, maka dapat menjadi evaluasi bagi guru dan TAS untuk meningkatkan kemampuan dan kinerjanya. Karena, penilaian yang dilakukan guru dan TAS terkait dengan kemampuan atau kinerjanya yang dilakukan oleh guru dan TAS sendiri, dapat berbeda dengan penilaian yang dilakukan oleh siswa tehadap kemampuan dan kinerja yang dilakukan guru dan TAS. Sebagai contoh, guru dalam melakukan proses pembelajaran menggunakan kompetensi yang dimilikinya yang kemudian kompetensi tersebut diimplementasikan dalam kegiatan pembelajaran, dalam proses pembelajaran tersebut, siswa dapat menilai kompetensi yang dimiliki guru tersebut apakah guru itu kompeten atau tidak dalam melakukan pembelajaran. Selanjutnya, TAS dalam melakukan pekerjaannya yakni memberikan pelayanan kepada siswa, siswa yang dilayani oleh TAS tersebut dapat memberikan penilaian terhadap pelayanan yang diberikan TAS tersebut kepada siswa apakah sudah baik atau belum. Sehingga, siswa dapat melakukan penilaian terhadap kinerja yang dilakukan guru dan TAS melalui kompetensi dan pelayanan yang dilakukan.

Kompetensi yang harus dimiliki oleh guru menurut Undang-Undang Nomor 14 Tahun 2005 tentang Guru dan Dosen ada empat yaitu: (1) kompetensi pedagogik, (2) kompetensi kepribadian, (3) kompetensi sosial, (4) kompetensi profesional yang diperoleh melalui pendidikan profesi. Sedangkan, menurut Maisyaroh, Wiyono, Burhanuddin dan Rasyad (2017) describe there are four componen teacher's skill that are skills in teaching, skills in managing core activities, skills in time management, and skills in assessing learning outcomes. Dalam melakukan kegiatan pembelajaran guru dapat menggunakan kompetensi-kompetensi tersebut. Sedangkan, TAS dalam memberikan pelayanan harus memperhatikan beberapa komponen dalam meberikan pelayanan. Menurut Tjiptono (2012) komponen dalam memberikan pelayanan prima ada lima yaitu: (1) reliabilitas, (2) daya tanggap, (3) jaminan, (4) empati, (5) bukti fisik.

Berdasarkan penelitian Chumaedi (2011) dengan judul Hubungan Kompetensi Pedagogik Guru dengan Motivasi Belajar Siswa Kelas X pada Mata Pelajaran Tarikh di SMA Muhammadiyah Sewon Bantul Yogyakarta menyatakan bahwa korelasi kompetensi pedagogik dengan motivasi 
belajar siswa kelas X SMA Muhammadiyah Sewon Bantul sebesar 0,170, angka tersebut dapat dikatakan bahwa hipotesis alternatif pertama diterima yakni terdapat hubungan antara kompetensi pedagogik guru dengan motivasi belajar siswa. Penelitian kedua, dilakukan oleh Shidiq (2011) dengan judul Hubungan Pelayanan Wali Kelas terhadap Motivasi Belajar Siswa Kelas I Jurusan Otomotif SMK Piri I Yogyakarta menyatakan bahwa terdapat hubungan positif dan signifikan antara pelayanan wali kelas dan motivasi belajar siswa kelas 1 jurusan otomotif SMK Piri 1 Yogyakarta yang dibuktikan dengan nilai rhitung sebesar 0,190 lebih besar dari rtabel 0,183 .

\section{METODE}

Pendekatan yang digunakan dalam penelitian ini ialah kuantitatif deskriptif. Penelitian ini bersifat deskriptif korelasional karena bertujuan untuk mengetahui ada atau tidaknya hubungan antara variabel kompetensi guru (X1), pelayanan TAS (X2), dan motivasi belajar (Y). Populasi dalam penelitian ini ialah siswa di SMA Negeri se-Kabupaten Sidoarjo dengan jumlah populasi 7.201 dan diperoleh 380 sampel. Teknik pengambilan dan penentuan sampel pada penelitian ini menggunakan sistematis proportional random sampling. Data yang digunakan dalam penelitian ini yaitu data kuantitatifjenis data interval. Instrumen penelitian ini menggunakan kuesioner (questionnaire) untuk mengukur fakta atau data yang bersifat fisik. Kuesioner yang digunakan menggunakan angket tertutup. Angket tertutup adalah "angket yang pertanyaan atau pernyataannya tidak memberikan kebebasan pada responden, untuk memberikan jawaban dan pendapatnya sesuai dengan keinginan mereka" (Hasan, 2002: 84). Kuesioner yang digunakan berupa model Skala Likert, dengan menggunakan alternatif jawaban antara lain: (1) SS/SL, (2) S/SR, (3) TS/JR, (4) STS/TP. Pengumpulan data dilakukan melalui empat tahap, yaitu; (1) tahap pengumpulan, (2) tahap pelaksanaan, (3) tahap pengolahan data, (4) tahap pelaporan. Analisis data yang digunakan ialah: (1) uji asumsi, yang meliputi uji normalitas dan uji linearitas, (2) analisis deskriptif, yaitu dengan menentukan panjang kelas interval dan menentukan persentase, (3) analisis korelasi product moment pearson, (4) analisis korelasi ganda.

\section{HASIL}

Hasil penelitian ini dapat dikelompokkan menjadi dua bagian, yaitu deskripsi data dan pengujian hipotesis. Hasil analisis deskriptif kompetensi guru, pelayanan TAS dan motivasi belajar disajikan pada Tabel 1, 2, dan 3 .

Deskripsi variabel kompetensi guru (sub variabel kompetensi pedagogik, kompetensi kepribadian, kompetensi sosial dan kompetensi profesional) disajikan pada Tabel 1.

Tabel 1 Kualifikasi dan Interval Nilai (X1)

\begin{tabular}{clcccc}
\hline No & $\begin{array}{c}\text { Alternatif } \\
\text { Jawaban }\end{array}$ & Interval & Kategori & Frekuensi & Persentase \\
\hline 1 & SS/SL & $134-164$ & Sangat tinggi & 219 & 57,6 \\
2 & S/SR & $103-133$ & Tinggi & 160 & 42,1 \\
3 & TS/JR & $72-102$ & Rendah & 1 & 0,3 \\
4 & STS/TP & $41-71$ & Sangat rendah & 0 & 0 \\
\hline & & TOTAL & & 380 & 100 \\
\hline
\end{tabular}

Sumber: Data Diolah Peneliti (2017)

Berdasarkan hasil perhitungan pada Tabel 1 menunjukkan bahwa dari 380 sampel responden yang digunakan dalam penelitian ini, sebanyak $(57,6 \%)$ responden menyatakan bahwa kompetensi yang dimiliki guru dalam kualifikasi sangat tinggi, kemudian (42,1\%) responden menyatakan bahwa kompetensi yang dimiliki guru dalam kualifikasi tinggi. Selanjutnya, $(0,3 \%)$ responden menyatakan bahwa kompetensi yang dimiliki guru dalam kualifikasi rendah, dan tidak ada responden yang menjawab sangat rendah.

Deskripsi variabel pelayanan TAS (sub variabel bukti fisik, keandalan, daya tanggap, jaminan, empati) dapat dilihat pada Tabel 2. 
Tabel 3 Kualifikasi dan Interval Nilai (Y)

\begin{tabular}{clcccc}
\hline No & $\begin{array}{c}\text { Alternatif } \\
\text { Jawaban }\end{array}$ & Interval & Kategori & Frekuensi & Persentase \\
\hline 1 & SS/SL & $86-105$ & Sangat tinggi & 190 & 50 \\
2 & S/SR & $66-85$ & Tinggi & 186 & 48,9 \\
3 & TS/JR & $46-65$ & Rendah & 64 & 1,1 \\
4 & STS/TP & $26-45$ & Sangat Rendah & 0 & 0 \\
\hline & & TOTAL & & 380 & 100 \\
\hline
\end{tabular}

Sumber: Data Diolah Peneliti (2017)

Berdasarkan hasil perhitungan pada Tabel 2 menunjukkan bahwa dari 380 sampel responden yang digunakan dalam penelitian ini, sebanyak $(50 \%)$ responden menyatakan bahwa pelayanan TAS dalam kualifikasi sangat tinggi, kemudian $(48,9 \%)$ responden menyatakan bahwa pelayanan TAS dalam kualifikasi tinggi. Selanjutnya,
$(1,1 \%)$ responden menyatakan bahwa pelayanan TAS dalam kualifikasi rendah, dan tidak ada responden yang menjawab sangat rendah.

Deskripsi variabel motivasi belajar (sub variabel motivasi intrinsik dan motivasi ekstrinsik) dapat dilihat pada Tabel 3.

Tabel 3 Kualifikasi dan Interval Nilai (Y)

\begin{tabular}{llcccc}
\hline No & $\begin{array}{c}\text { Alternatif } \\
\text { Jawaban }\end{array}$ & Interval & Kategori & Frekuensi & Persentase \\
\hline 1. & SS/SL & $86-105$ & Sangat tinggi & 140 & 36,8 \\
2. & S/SR & $66-85$ & Tinggi & 228 & 60 \\
3. & TS/JR & $46-65$ & Rendah & 12 & 3,2 \\
4. & STS/TP & $26-45$ & Sangat rendah & 0 & 0 \\
\hline & & TOTAL & & 380 & 100 \\
\hline
\end{tabular}

Sumber: Data Diolah Peneliti (2017)

Berdasarkan hasil perhitungan pada Tabel 3 menunjukkan bahwa dari 380 sampel responden yang digunakan dalam penelitian ini, sebanyak $(36,8 \%)$ responden menyatakan bahwa motivasi belajar yang dimiliki dalam kualifikasi sangat tinggi, kemudian $(60 \%)$ responden menyatakan bahwa motivasi belajar yang dimiliki dalam kualifikasi tinggi. Selanjutnya, (3,2\%) responden menyatakan bahwa motivasi belajar yang dimiliki dalam kualifikasi rendah, dan tidak ada responden yang menjawab sangat rendah.

Pengujian hipotesis ini dilakukan untuk tiga hipotesis penelitian. Hasil hipotesisnya diuraikan secara berurutan sebagai berikut.

\section{Pengujian Hipotesis 1}

Hipotesis yang diuji secara statistik dalam penelitian ini yaitu "terdapat hubungan yang signifikan antara kompetensi guru dan motivasi belajar siswa". Hasil analisis korelasi yang dilakukan menunjukkan Pada T X1 (total variabel kompetensi) diperoleh nilai signifikansi 2-tailed sebesar $0,000<0,05$. Hal tersebut menunjukkan bahwa $\mathrm{H} 0$ ditolak dan $\mathrm{H} 1$ diterima sehingga dapat diartikan terdapat hubungan yang signifikan antara kompetensi guru dan motivasi belajar siswa di SMA Negeri se-Kabupaten Sidoarjo.

\section{Pengujian Hipotesis 2}

Hipotesis yang diuji secara statistik dalam penelitian ini yaitu "terdapat hubungan yang signifikan antara pelayanan TAS dan motivasi belajar siswa". Hasil analisis korelasi yang dilakukan menunjukkan Pada T X2 (total variabel pelayanan) diperoleh nilai signifikansi 2-tailed sebesar $0,000<0,05$. Hal tersebut menunjukkan bahwa $\mathrm{H} 0$ ditolak dan $\mathrm{H} 1$ diterima sehingga dapat diartikan terdapat hubungan yang signifikan antara pelayanan TAS dan motivasi belajar siswa di SMA Negeri se-Kabupaten Sidoarjo.

\section{Pengujian Hipotesis 3}

Hipotesis yang diuji secara statistik dalam penelitian ini yaitu "terdapat hubungan yang signifikan antara kompetensi guru, pelayanan 
TAS, dan motivasi belajar siswa". Hasil analisis korelasi yang dilakukan menunjukkan perolehan nilai signifikansi 0,000 . Dengan begitu, nilai signifikansi lebih kecil dari nilai probabilitas 0,05 atau nilai $0,000<0,05$. Maka $\mathrm{H} 0$ ditolak dan H1 diterima, artinya ada hubungan yang positif sehingga terjadi hubungan yang signifikan antara kompetensi guru, pelayanan TAS dan motivasi belajar siswa di SMA Negeri se-Kabupaten Sidoarjo.

\section{PEMBAHASAN}

\section{Hubungan Kompetensi Guru dan Motivasi Belajar Siswa di SMA Negeri se- Kabupaten Sidoarjo}

Berdasarkan hasil perhitungan korelasi Product Momen Pearson diperoleh nilai signifikansi 0,000 . Dengan begitu, nilai signifikansi lebih kecil dari nilai probabilitas 0,05 atau nilai $0,000<0,05$. Maka $\mathrm{H} 0$ ditolak dan H1 diterima, artinya ada hubungan yang terjadi antara kompetensi guru dengan motivasi belajar siswa di SMA Negeri se-Kabupaten Sidoarjo.

Guru dalam melakukan kegiatan pembelajaran dituntut memiliki kemampuan atau kompetensi yang dapat menunjang proses belajar mengajar. Menurut Robbins (1996, dalam Mulyono, 2012) kemampuan merujuk kepada kecepatan seseorang untuk mengerjakan beberapa tugas dalam suatu pekerjaan. Adanya kompetensi yang dimiliki guru dapat membuat siswa termotivasi dalam melakukan kegiatan pembelajaran. Menurut Novandi (2013) motivasi belajar adalah kekuatan yang menjadi dasar penggerak dan sebagai petunjuk bagi peserta didik untuk melakukan kegiatan pembelajaran agar pengetahuan, pemahaman, dan keterampilannya meningkat.

Berdasarkan hasil penelitian yang dilakukan peneliti, bahwa terdapat hubungan antara kompetensi guru dengan motivasi belajar siswa. Sehingga, dari hasil penelitian tersebut menjelaskan bahwa kompetensi-kompetensi yang dimiliki guru sangat berpengaruh terhadap motivasi belajar siswa. Adapun kompetensi yang harus dimiliki guru yaitu kompetensi pedagogik, kompetensi kepribadian, kompetensi sosial, dan kompetensi profesional. Keempat kompetensi tersebut berpengaruh dalam memotivasi belajar siswa. Motivasi belajar siswa terdiri dari motivasi intrinsik dan ekstrinsik. Motivasi itrinsik lebih kuat dan efektif jika dibandingkan dengan motivasi ekstrinsik. Karena, motivasi intrinsik ini tumbuh dan berasal dari dalam diri siswa.

Temuan hasil penelitian terdahulu yang sesuai dengan hasil penelitian yang dilakukan peneliti adalah penelitian yang dilakukan oleh Solihah (2011) dengan judul Hubungan antara Kompetensi Guru dengan Motivasi Belajar pada Siswa Boarding School SMP Plus Al-Aqsha di Jatinagor Sumedang menyatakan bahwa Hasil analisis data secara statistik memperlihatkan koefisin korelasi antara kompetensi guru dengan motivasi belajar bahwa nilai probabilitas sebesar 0,001 lebih kecil dari 0,05. Hal tersebut memiliki arti bahwa $\mathrm{H} 0$ dalam penelitian ini ditolak, artinya terdapat hubungan positif antara kompetensi guru dengan motivasi belajar siswa kelas 3 SMP Plus Al-Aqsha.

Penelitian kedua, dilakukan oleh Chumaedi (2011) dengan judul Hubungan Kompetensi Pedagogik Guru dengan Motivasi Belajar Siswa Kelas X pada Mata Pelajaran Tarikh di SMA Muhammadiyah Sewon Bantul Yogyakarta menyatakan bahwa korelasi kompetensi pedagogik dengan motivasi belajar siswa kelas X SMA Muhammadiyah Sewon Bantul sebesar 0,170, angka tersebut dapat dikatakan bahwa hipotesis alternatif pertama diterima yakni terdapat hubungan antara kompetensi pedagogik guru dengan motivasi belajar siswa. Dalam penelitian yang dilakukan oleh peneliti dan penelitian yang dilakukan oleh Solihah dan Chumaedi bahwa dalam penelitian tersebut hasilnya sama-sama terdapat hubungan antara kompetensi guru dengan motivasi belajar siswa. Namun, variabel yang digunakan peneliti dan penelitian yang dilakukan oleh Solihah dan Chumaedi berbeda. Tidak hanya itu saja, lokasi dan responden yang digunakan oleh peneliti juga berbeda dengan responden yang digunakan oleh Solihah dan Chumaedi.

\section{Hubungan Pelayanan Tenaga Administrasi Sekolah (TAS) dan Motivasi Belajar Siswa di SMA Negeri se-Kabupaten Sidoarjo}

Berdasarkan hasil perhitungan korelasi Product Momen Pearson diperoleh nilai signifikansi 0,000 . Dengan begitu, nilai 
signifikansi lebih kecil dari nilai probabilitas 0,05 atau nilai $0,000<0,05$. Maka $\mathrm{H} 0$ ditolak dan H1 diterima, artinya ada hubungan yang terjadi antara pelayanan TAS dengan motivasi belajar siswa di SMA Negeri se-Kabupaten Sidoarjo.

Pelayanan merupakan suatu kegiatan untuk menyediakan dan melaksanakan apa saja yang dibutuhkan individu. Dalam melakukan pelayanan harus dilakukan dengan prima. Adanya pelayanan yang baik dapat membuat seseorang yang dilayani merasa puas sehingga dapat menciptakan citra organisasi yang baik di kalangan masyarakat. Sedangkan, motivasi belajar merupakan dorongan pada diri siswa untuk melakukan perubahan yang ditandai dengan adanya tindakan belajar. Dari hasil penelitian yang dilakukan peneliti, bahwa terdapat hubungan antara pelayanan TAS dengan motivasi belajar siswa. Dalam pelayanan TAS tersebut mengandung beberapa komponen yang mendukung dalam memotivasi belajar siswa. Adapun komponen tersebut yaitu reliabilitas, daya tanggap, jaminan, empati, dan bukti fisik. Komponen tersebut juga sesuai dengan komponen yang dijelaskan oleh Parasuraman, dkk (1993, dalam Parwitasari, 2016) yaitu: (a) reliabilitas (reliability), berkaitan dalam kemampuan memberikan pelayanan; (b) daya tanggap (responsiveness), berkaitan dengan kesediaan dan kemampuan individu dalam melayani; (c) jaminan (assurance), berkaitan dengan pengetahuan dan kesopanan dalam melayani; (d) empati (empathy), berkaitan dengan memberikan perhatian dalam melayani; (e) bukti fisik (tangibles), berkaitan dengan keadaan fisik fasilitas layanan, perlengkapan, maupun sumber daya manusia.

Temuan hasil penelitian terdahulu yang sesuai dengan hasil penelitian yang dilakukan peneliti adalah penelitian yang dilakukan oleh Atmoko (2016) dengan judul Hubungan Layanan Bimbingan Belajar dengan Motivasi Belajar Siswa Kelas VIII SMP Negeri 3 Kasihan Tahun Pelajaran 2015/2016 menyatakan bahwa terdapat hubungan positif layanan bimbingan belajar dengan motivasi belajar Siswa kelas VIII SMP Negeri 3 Kasihan Bantul Yogyakarta tahun ajaran 2015/2016 dengan mengetahui harga $r$ hitung sebesar 0,410 dan $p=0,001<0,05$ pada taraf signifikansi $5 \%$.
Penelitian kedua dilakukan oleh Shidiq (2011) dengan judul Hubungan Pelayanan Wali Kelas terhadap Motivasi Belajar Siswa Kelas I Jurusan Otomotif SMK Piri I Yogyakarta menyatakan bahwa terdapat hubungan positif dan signifikan antara pelayanan wali kelas dan motivasi belajar siswa kelas 1 jurusan otomotif SMK Piri 1 Yogyakarta yang dibuktikan dengan nilai rhitung sebesar 0,190 lebih besar dari rtabel 0,183 .

Penelitian yang dilakukan oleh peneliti dengan penelitian yang dilakukan oleh Atmoko dan Shidiq adalah bahwa dalam penelitiannya sama-sama terdapat hubungan antara pelayanan dengan motivasi belajar siswa. Namun, ada perbedaan penelitian yang dilakukan peneliti dengan penelitian Atmoko dan Shidiq dari sisi variabelnya, serta dari sisi lokasi penelitian serta responden yang digunakan dalam penelitian.

\section{Hubungan Kompetensi Guru, Pelayanan Tenaga Administrasi Sekolah (TAS) dan Motivasi Belajar Siswa di SMA Negeri se- Kabupaten Sidoarjo}

Berdasarkan hasil perhitungan korelasi ganda diperoleh nilai signifikansi 0,000. Dengan begitu, nilai signifikansi lebih kecil dari nilai probabilitas 0,05 atau nilai $0,000<0,05$. Maka $\mathrm{H} 0$ ditolak dan H1 diterima, artinya ada hubungan yang positif sehingga terjadi hubungan yang signifikan antara kompetensi dan pelayanan dengan motivasi belajar di SMA Negeri se-Kabupaten Sidoarjo.

Dalam suatu sekolah, pendidik dan tenaga kependidikan mempunyai peranan penting untuk memajukan sekolah yakni meningkatkan mutu pendidikan di sekolah tersebut. Salah satu upaya untuk meningkatkan mutu pendidikan tersebut yaitu dengan meningkatkan prestasi dari siswasiswi di sekolah tersebut.

Upaya yang dapat dilakukan untuk meningkatkan prestasi siswa tersebut yaitu dengan cara memotivasi siswa dalam belajar sehingga dengan adanya semangat dalam belajar dapat meningkatkan prestasi siswa. Guru sebagai pendidik dalam memotivasi siswa dapat dilakukan dengan meningkatkan kompetensinya. Sedangkan, TAS sebagai tenaga kependidikan dalam memotivasi siswa dapat dilakukan dengan cara memberikan pelayanan prima yang baik kepada siswa. 
Komponen yang termuat dalam kompetensi guru sendiri ada empat yakni kompetensi pedagogik, kompetensi kepribadian, kompetensi sosial, dan kompetensi profesional. Sedangkan, komponen yang termuat dalam pelayanan TAS ada lima, yakni reliabilitas, daya tanggap, jaminan, empati, dan bukti fisik. Guru dan TAS harus saling bekerja sama untuk menciptakan mutu pendidikan yang berkualitas dengan meningkatkan prestasi peserta didik melalui pemberian motivasi belajar agar siswa semangat dalam proses pembelajaran. Dengan begitu, maka tujuan dari pendidikan dapat tercapai dengan baik.

Dari hasil penelitian yang dilakukan peneliti, memperoleh hasil yang sesuai dengan penelitian yang dilakukan oleh Chumaedi (2011) dengan judul Hubungan Kompetensi Pedagogik Guru dengan Motivasi Belajar Siswa Kelas X pada Mata Pelajaran Tarikh di SMA Muhammadiyah Sewon Bantul Yogyakarta menyatakan bahwa korelasi kompetensi pedagogik dengan motivasi belajar siswa kelas X SMA Muhammadiyah Sewon Bantul, penelitian kedua oleh Solihah (2011) dengan judul Hubungan antara Kompetensi Guru dengan Motivasi Belajar pada Siswa Boarding School SMP Plus Al-Aqsha di Jatinagor.

Penelitian ketiga oleh Shidiq (2011) dengan judul Hubungan Pelayanan Wali Kelas terhadap Motivasi Belajar Siswa Kelas I Jurusan Otomotif SMK Piri I Yogyakarta, dan penelitian keempat oleh Atmoko (2016) dengan judul Hubungan Layanan Bimbingan Belajar dengan Motivasi Belajar Siswa Kelas VIII SMP Negeri 3 Kasihan Tahun Pelajaran 2015/2016 menyatakan bahwa terdapat hubungan positif layanan bimbingan belajar dengan motivasi belajar Siswa kelas VIII SMP Negeri 3 Kasihan Bantul Yogyakarta yakni dalam hasil penelitian tersebut samasama terdapat hubungan antara kompetensi dan pelayanan dengan motivasi belajar.

Dalam penelitian tersebut, hasilnya sesuai dengan penelitian oleh Chumaedi, Solihah, Shidiq, dan Atmoko yakni sama-sama ada hubungan yang signifikan antara kompetensi dan pelayanan dengan motivasi belajar. Perbedaan penelitian yang dilakukan, dapat dilihat dari sisi variabel penelitian yang digunakan, sisi responden penelitian, dan lokasi penelitian yang digunakan.

\section{SIMPULAN DAN SARAN}

\section{Simpulan}

Berdasarkan hasil penelitian dan hasil pembahasan maka dapat ditarik kesimpulan sebagai berikut: (1) tingkat kompetensi guru di SMA Negeri se-Kabupaten Sidoarjo dalam kualifikasi sangat tinggi, (2) tingkat pelayanan Tenaga Administrasi Sekolah (TAS) di SMA Negeri se-Kabupaten Sidoarjo dalam kualifikasi sangat tinggi, (3) tingkat motivasi belajar siswa di SMA Negeri se-Kabupaten Sidoarjo dalam kualifikasi tinggi, (4) terdapat hubungan yang signifikan antara kompetensi guru dengan motivasi belajar siswa, (5) terdapat hubungan yang signifikan antara pelayanan Tenaga Administrasi Sekolah (TAS) dengan motivasi belajar siswa, (6) terdapat hubungan yang signifikan antara kompetensi guru dan pelayanan Tenaga Administrasi Sekolah (TAS) dengan motivasi belajar siswa.

\section{Saran}

Penelitian ini memberikan saran kepada: (1) kepala SMA Negeri se-Kabupaten Sidoarjo, kepala sekolah diharapkan memperhatikan kompetensi profesional guru, karena kompetensi tersebut masih rendah. Selain itu, kepala sekolah juga harus memperhatikan Tenaga Administrasi Sekolah (TAS) dalam memberikan pelayanan khususnya dalam hal ketanggapan TAS dalam melayani siswa yang dilayani. Karena, komponen ketanggapan TAS dalam melayani siswa masih rendah. Bentuk perhatian kepala sekolah tersebut misalnya dengan memberikan arahan kepada guru dan TAS, (2) guru SMA Negeri se-Kabupaten Sidoarjo diharapkan dapat lebih meningkatkan empat kompetensi yang telah dimiliki untuk mencapai keberhasilan tujuan dari proses pembelajaran. Khususnya dalam kompetensi profesional yang masih rendah agar lebih ditingkatkan lagi. Adanya penelitian ini diharapkan dapat dijadikan sebagai bahan evaluasi bagi guru untuk meningkatkan kompetensi agar lebih baik lagi khususnya dalam kompetensi profesional, (3) tenaga administrasi sekolah (TAS) SMA Negeri se-Kabupaten Sidoarjo diharapkan terus meningkatkan pelayanan agar dapat bekerja secara maksimal. Khususnya dalam hal ketanggapan TAS dalam melayani siswa yang masih rendah. Hasil penelitian ini diharapkan mampu dijadikan sebagai bahan mengevaluasi 
diri dan meningkatkan kinerja dalam memberikan pelayanan prima yang lebih baik lagi kepada siswa, (4) ketua jurusan administrasi pendidikan, hasil penelitian ini dapat dijadikan sebagai bahan pertimbangan untuk mengambil kebijakan dalam mengembangkan matakuliah manajemen sumber daya manusia, (5) mahasiswa jurusan administrasi pendidikan, diharapkan hasil penelitian ini dapat dijadikan sebagai tambahan referensi sumber belajar bagi mahasiswa jurusan administrasi pendidikan khususnya pada matakuliah sumber daya manusia, (6) peneliti selanjutnya, hasil penelitian ini diharapkan dapat dijadikan sebagai referensi bagi peneliti yang akan melakukan penelitian selanjutnya. Diharapkan peneliti lain yang akan melakukan penelitian terkait dengan manajemen sumber daya manusia yang seperti dilakukan peneliti menggunakan variabel yang lain yang selaras dengan manajemen sumber daya manusia.

\section{DAFTAR RUJUKAN}

Atmoko, T.A.B. 2016. Hubungan Layanan Bimbingan Belajar dengan Motivasi Belajar Siswa Kelas Viii Smp Negeri 3 Kasihan Tahun Pelajaran 2015/2016, (Online), (http://repository.upy. ac.id), diakses tanggal 05 Oktober 2017.

Chumaedi,A. 2011. Hubungan Kompetensi Pedagogik Guru dengan Motivasi Belajar Siswa Kelas X pada Mata Pelajaran Tarikh di SMA Muhammadiyah Sewon Bantul, (Online), (http://digilib.uin-suka. ac.id), diakses tanggal 05 Oktober 2017.

Erlanggono, E. \& Kurniawan, E.S. \& Sriyono. 2012. Peningkatan Motivasi Berprestasi Siswa IPA Fisika dengan Memanfaatkan Computer Assisted Instruction (CAI) pada Siswa SMP Negeri 6 Purworejo. Jurnal Pendidikan Fisika, (Online), Vol. 02 No. 01, (http://id.portalgaruda.org), diakses tanggal 02 Oktober 2017.

Hasan, I. 2002. Pokok-Pokok Materi Metodologi Penelitian \& Aplikasinya, Ghalia: Indonesia.

Maisyaroh \& Wiyono, B.W. \& Burhanuddin \& Rasyad. 2012. The Relation of Educational Supervision and Teacher's Teaching Skills. Advanced in Economics, Business and Management Research,
(Online), Vol. 45, (http://creativecommons.org/ licenses/by-nc/4.0/), diakses tanggal 10 Februari 2018.

Mulyasa. 2008. Standar Kompetensi dan Sertifikasi Guru. Bandung: PT Remaja Rosdakarya Offset.

Mulyono. 2012. Pengaruh Kesesuaian Kompetensi dan Motivasi Kerja Terhadap Kinerja Pegawai Negeri Sipil Bagian Administrasi pada Sekolah Menengah Atas Negeri Kota Malang. Jurnal Manajemen dan Akuntansi, (Online), Vol. 01 No. 01, (http://id.portalgaruda.org), diakses tanggal 02 November 2016.

Mustiningsih. 2009. Psikologi Pendidikan. Malang: Universitas Negeri Malang.

Novandi, R. 2013. Pengaruh Motivasi Belajar dan Lingkungan Teman Sebaya terhadap Prestasi Belajar Akuntansi Keuangan Siswa Kelas X1 AK SMK Negeri 7 Yogyakarta tahun Ajaran 2011/2012, (Online), Vol. 02 No. 01, (ttps:// journal.uny.ac.id), diakses tanggal 05 Oktober 2017.

Prihastono, E. 2012. Pengukuran Kepuasan Konsumen pada Kualitas Pelayanan Customer Service berbasis WEB. Jurnal Ilmiah Dinamika Teknik, (Online), (download.portalgaruda.org), diakses tanggal 05 Oktober 2017.

Shidiq, M.L. 2011. Hubungan Pelayanan Wali Kelas terhadap Motivasi Belajar Siswa Kelas I Jurusan Otomotif SMK Piri I Yogyakarta, (Online), (eprints.uny.ac.id), diakses tanggal 11 Oktober 2017.

Solihah, S.H. 2011. Hubungan antara Kompetensi Guru dengan Motivasi Belajar pada Siswa Boarding School SMP Plus Al-Aqsha di Jatinangor Sumedang, (Online), ( http://digilib. uinsgd.ac.id), diakses tanggal 05 Oktober 2017.

Sopiatin, P. 2010. Manajemen Belajar Berbasis Kepuasan Siswa. Bogor: Ghalia Indonesia.

Tjiptono, F. 2012. Service Management (Mewujudkan Pelayanan Prima). Yogyakarta: CV. Andi Offset.

Undang-Undang Nomor 14 Tahun 2005 tentang Guru dan Dosen, (Online), (http://luk.staff.ugm.ac.id), diakses tanggal 02 Oktober 2017.

Zulkarnain, W. \& Sumarsono, R.B. 2011.Manajemen Perkantoran Pendidikan. Fakultas Ilmu Pendidikan Universitas Negeri Malang. 